\title{
Ramsay Hunt Syndrome: A Clinical Management Experience from a Secondary Care Public Hospital
}

\author{
Madhubala Balasubramanian', Indu Tharayappurath Haridas' ${ }^{1}$, B Jeyaganeshamoorthi ${ }^{2}$, Sivasankaran \\ Ponnusankar ${ }^{1 *}$
}

1Department of Pharmacy Practice, JSS College of Pharmacy, Udhagamandalam-643001, JSS University, Mysuru, Karnataka, INDIA. ${ }^{2}$ Government District Head Quarters Hospital, Udhagamandalam-643001, The Nilgiris, Tamilnadu, INDIA.

\begin{abstract}
Introduction: Ramsay Hunt Syndrome is a rare and severe infection caused by varizella zoster virus. Case: The present case describes the manifestations and treatment strategies followed for a 70-year-old woman who visited to a secondary care hospital, Udhagamandalam. The presence of facial palsy, bell's palsy, difficulty in closing the eyes, otalgia and shingles confirmed Ramsay Hunt Syndrome. The early management with acyclovir and prednisolone had shown improvement in clinical outcome of the patient. However, as a preventive measure, it is essential to undergo immunization with varizella vaccine in elder people in this locality.
\end{abstract}

Key words: Ramsay hunt syndrome, VZV, Facial palsy, Acyclovir, Management.

\section{INTRODUCTION}

Ramsay Hunt Syndrome (RHS) or Herpes Zoster Oticus (HZO) is a rare clinical entity with a global incidence rate of 5 in 1,00,000., The reactivation of varizella zoster virus $(\mathrm{VZV})$, in a patient who was affected with chickenpox earlier can be the root cause for this condition. The microorganism may survive in inactivated stage for a long time in geniculate ganglia, which involves in the regulation of facial nerves. Thus, RHS is associated with symptoms such as facial paralysis, ear pain and vesicular lesions and can be managed with corticosteroids, antiviral agents, analgesics and eye lubricants., ${ }^{2,3}$ The clinical presentations and treatment pattern followed for a patient with RHS in a secondary care hospital, Udhagamandalam is described in this report.

\section{CASE REPORT}

A 70-year-old woman was presented to the in-patient department of female medical unit of secondary care public hospital, Udhagamandalam, The Nilgiris on $13^{\text {th }}$ July 2015. Patient had the complaints of difficulty in closing the left eye due to nystagmus, vertigo and left ear pain for 3 days. Later, it was turned to the deviation of angle of mouth on the left side and was being unable to hold water or food in mouth due to the weakness of facial muscles. The patient had a history of hypertension for past seven years and was on treatment of Tablet Amlodipine $2.5 \mathrm{mg}(1-0-1)$. The vitals of the patient were as follows; blood pressure: 140/80 $\mathrm{mmHg}$, pulse rate: $74 \mathrm{beats} / \mathrm{min}$, respiratory rate: 20 breaths/min and temperature 98.4 ${ }^{\circ} \mathrm{F}$. The lab investigation details are given in Table 1. Physical examination by ENT consultant confirmed facial palsy on the left side and diagnosed as RHS. The patient was immediately administered with antiviral Tab. Acyclovir 800 mg (1-1-1-1-1) along with Tab. Prednisolone 5 mg (1-0-1), Cap. Omeprazole 20 mg (1-0-1), intravenous fluid (IVF) infusion of dextrose normal saline 1 pint $(100 \mathrm{ml} / \mathrm{hr}$.) and Tab. Amlodipine 2.5 mg (1-0-1).

On day 2, patient developed left bell's palsy, shingles (painful rashes with blisters) on the
DOI: 10.5530/ijopp.10.3.48

Address for correspondence: Dr. S Ponnusankar, Professor and Head Department of Pharmacy Practice, JSS College of Pharmacy, Rocklands, Post Box No. 20, Ooty-643001, The Nilgiris, Tamil Nadu, INDIA. Phone no: 0423-2443393, 2443847, H/P: +91-94896 13428 Email Id: ponnusankarsivas@ gmail.com

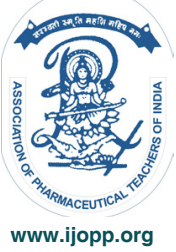




\begin{tabular}{|c|c|c|}
\hline Clinical parameters & Value in patient & Normal range \\
\hline Hemoglobin & $13.0 \mathrm{~g} / \mathrm{dL}$ & $12-16 \mathrm{~g} / \mathrm{dL}$ \\
\hline Total Count (TC) & $5.7 \times 10^{3} / \mu \mathrm{L}$ & 3.2-9.8 $\times 10^{3}$ cells $/ \mathrm{mm}^{3}$ \\
\hline $\begin{array}{c}\text { Differential Count (DC) } \\
\text { Polymorphs } \\
\text { Lymphocytes } \\
\text { Monocytes }\end{array}$ & $\begin{array}{c}68 \% \\
23 \% \\
9 \%\end{array}$ & $\begin{array}{c}54-62 \% \\
25-33 \% \\
3-7 \%\end{array}$ \\
\hline Platelet count (Pt) & $191 \times 10^{3} / \mu \mathrm{L}$ & $130-400 \times 10^{3} / \mathrm{mm}^{3}$ \\
\hline Red Blood Cells (RBC's) & $4.92 \times 10^{6} / \mu \mathrm{L}$ & $3.5-5.0 \times 10^{6} / \mathrm{mm}^{3}$ \\
\hline Hematocrit & $42.0 \%$ & $33-43 \%$ \\
\hline Mean cell volume (MCV) & $55.4 \mathrm{fL}$ & $76-100 \mu \mathrm{m}^{3}$ \\
\hline Mean cell hemoglobin $(\mathrm{MCH})$ & $26.4 \mathrm{pg} / \mathrm{cell}$ & $27-33 \mathrm{pg} / \mathrm{cell}$ \\
\hline $\begin{array}{l}\text { Mean cell hemoglobin concentration } \\
\qquad(\mathrm{MCHC})\end{array}$ & $31.0 \mathrm{~g} / \mathrm{dL}$ & $33-37 \mathrm{~g} / \mathrm{dL}$ \\
\hline Random blood sugar (RBS) & $115 \mathrm{mgs} \%$ & $<200 \mathrm{mg} / \mathrm{dL}$ \\
\hline Blood urea & $33 \mathrm{mgs} \%$ & $20-40 \mathrm{mg} / \mathrm{dL}$ \\
\hline Serum creatinine (Sr.cr) & $0.8 \mathrm{mgs} \%$ & $0.6-1.2 \mathrm{mg} / \mathrm{dL}$ \\
\hline Aspartate aminotransferase (SGOT) & $34 \mathrm{U} / \mathrm{L}$ & $0-35 \mathrm{U} / \mathrm{L}$ \\
\hline Alanine aminotransferase (SGPT) & $30 \mathrm{U} / \mathrm{L}$ & $0-35 U / L$ \\
\hline Alkaline phosphates (ALP) & $67 \mathrm{U} / \mathrm{L}$ & $30-120 \mathrm{U} / \mathrm{L}$ \\
\hline $\begin{array}{l}\text { Bilirubin } \\
\text { Total } \\
\text { Direct } \\
\text { Indirect }\end{array}$ & $\begin{array}{l}0.5 \mathrm{mgs} \% \\
0.2 \mathrm{mgs} \% \\
0.3 \mathrm{mgs} \%\end{array}$ & $\begin{array}{c}0.1-1 \mathrm{mg} / \mathrm{dL} \\
0-0.2 \mathrm{mg} / \mathrm{dL} \\
0.1-0.8 \mathrm{mg} / \mathrm{dL}\end{array}$ \\
\hline $\begin{array}{l}\text { Urine Analysis } \\
\text { Urine sugar } \\
\text { Urine albumin } \\
\text { Pus cells }(p c) \\
\text { Epithelial pus sells (epc) }\end{array}$ & $\begin{array}{l}\text { Nil } \\
\text { Nil } \\
2-3 / \mathrm{hpf} \\
4-5 / \mathrm{hpf}\end{array}$ & $\begin{array}{c}\text { Nil } \\
\text { Nil } \\
1-2 / h p f \\
1-2 / h p f\end{array}$ \\
\hline
\end{tabular}

left ear, which are the classical signal of reactivation of chicken pox virus. Tab. Carbamazepine 200mg (1-0-1) was added to the prescription to relieve the neuropathic pain and the same was continued for day 3. On day 4, patient had complaints of vomiting and Tab. Prochlorperazine $125 \mathrm{mg}(1-0-1)$ was also added to the prescription to treat vomiting and vertigo. The treatment was continued for the next 3 days (till $9^{\text {th }}$ day) along with physiotherapy. The use of certain protective measure to the eye such as covering the eye with cloths and eye lubricants was recommended to the patient by ophthalmologist.

She was discharged on the $9^{\text {th }}$ day with the medications such as Tab. Acyclovir $500 \mathrm{mg}$ (1-1-1-1-1) for 25 days, Tab. Amlodipine $2.5 \mathrm{mg}(0-0-1)$, Cap Omeprazole $20 \mathrm{mg}$ (0-0-1) for 15 days, Tab. Prednisolone $5 \mathrm{mg}(0-0-1)$ for 10 days and Tab. Carbamazepine $200 \mathrm{mg}$ (1-0-1) for 30 days. Patient was advised to visit the outpatient department of the hospital on regular basis for the necessary dose tapering and monitoring the treatment prognosis.

\section{DISCUSSION}

The manifestations shown in this patient such as unilateral facial paralysis, vesicular rashes on the ear and severe pain confirmed the diagnosis of RHS. This rare scenario may be raised due to the reactivation of varicella zoster virus. The involvement of herpes zoster virus was also suspected in this patient due to the appearance of skin lesions with Bell 's palsy. The presence of varicella zoster virus and berpes zoster virus together in one patient is not very common. ${ }^{2}$ The proper differentiation is possible only by polymerized chain reaction and serological assays. ${ }^{4}$ However, the standard treatment guidelines recommend acyclovir (800 mg, five times daily) and prednisolone (60 mg daily) for 3-5 days in both conditions and the same was followed in this patient. ${ }^{5}$

Corticosteroids may reduce facial palsy and inflammation whereas, acyclovir may reduce the duration of treatment and complications in the eye. ${ }^{4,6}$ The recovery from RHS is early when these two drugs are given together than giving individually. Being an antimicrobial agent, acyclovir 
can work against herpes zoster virus also, when given as orally or parenterally without any variation. ${ }^{7}$ Oral route of administration was preferred in this patient due to its cost effectiveness. The eye lubricants moisturize and protect the patient from further infection and injury to the eye and carbamazepine was given to relieve neuropathic pain. ${ }^{8}$ Thus, the treatment provided to the patient was found to be in line with the standard management of Ramsay Hunt Syndrome. The other recommended drugs are valacyclovir, famciclovir, penciclovir and brivudine. ${ }^{7}$

RHS is less frequently seen in children but, it is more common in geriatric people of both genders, due to the loss of cellular and humoral immunity., ${ }^{3,4}$ The rate of inflammatory reactions was also found to be common among these patients. ${ }^{9}$ The presence of hypertension in RHS patients above 60 years may increase the risk of unilateral Bells' palsy and delay the improvement. ${ }^{10,11}$ However, the timely administration of drugs enabled the present patient for a proper recovery.

The rehabilitation program for facial palsy recommended includes facial massage, facial exercises such as smiling, grimacing and whistling for two times per week. It is also recommended for the immunization in persons above 60 years or elder to boost their cell mediated immunity with VZV vaccine for preventing the attack of RHS in future. ${ }^{12}$

\section{CONCLUSION}

Ramsay Hunt Syndrome, associated with facial palsy is a less frequently observed clinical entity. The case was well managed in this secondary care hospital with a treatment including acyclovir and corticosteroids. However, it is recommended to undergo immunization with $\mathrm{VZV}$ in elder people in this locality as a preventive measure.

\section{ACKNOWLEDGMENT}

The authors acknowledge the support provided by the Government Headquarters Hospital, Udhagamandalam.

\section{Financial Support and Sponsorship}

Nil.

\section{CONFLICTS OF INTEREST}

There are no conflicts of interest.

\section{REFERENCES}

1. Adour KK. Otological complications of herpes zoster. Ann Neurology. 1994;35(S1):62-4.

2. Gondivkar S, Parikh V, Parikh R. Herpes zoster oticus: A rare clinical entity. Contemporary Clinical Dent. 2010;1(2):127-9.

3. Zainine R, Sellami M, Charfeddine A, Beltaief N, Sahtout S, Besbes G. Ramsay Hunt syndrome. Eur Ann Otorhinolaryngol Head Neck Dis. 2012;129(1):22-5.

4. Murakami S, Honda N, Mizobuchi M, Nakashiro Y, Hato N, Gyo K. Rapid diagnosis of varicella zoster virus infection in acute facial palsy. Neurology. 1998;51(4):1202-5.

5. Sweeney CJ, Gilden DH. Ramsay Hunt syndrome. J Neurology Neurosurgery Psychiatry 2001;71(2):149-54

6. Wagner G, Klinge H, Sachse MM. Ramsay Hunt syndrome. J Dtsch Dermatol Ges. 2012;10(4):238-43.

7. Dorsky DI, Crumpacker CS. Drugs five years later: acyclovir. Ann Intern Med. 1987;107(6):859-74.

8. Wiffen PJ, Derry S, Moore RA, Kalso EA. Carbamazepine for chronic neuropathic pain and fibromyalgia in adults. Cochrane Database Systematic Rev. 2014:10;(4):CD005451.

9. Goldani LZ, Silva LF, Dora JM. Ramsay Hunt syndrome in patients infected with human immunodeficiency virus. Clinical Experimental Dermatology. 2009;34(8):e552-4.

10. Juliana OFS, Fernanda. Ramsay Hunt Syndrome: case report. Am Med J. 2012;3:237-9.

11. Morgan M, Nathwani D. Facial palsy and infection: the unfolding story. Clinical Infect Dis. 1992;14(1):263-71.

12. Oxman MN. Immunization to reduce the frequency and severity of herpes zoster and its complications. Neurology. 1995;45(12 Supple 8):41-6. 